\title{
Irrigation method does not affect wild bee pollinators of hybrid sunflower
}

\author{
by Hillary Sardiñas, Collette Yee and Claire Kremen
}

\begin{abstract}
Irrigation method has the potential to directly or indirectly influence populations of
\end{abstract} wild bee crop pollinators nesting and foraging in irrigated crop fields. The majority of wild bee species nest in the ground, and their nests may be susceptible to flooding. In addition, their pollination of crops can be influenced by nectar quality and quantity, which are related to water availability. To determine whether different irrigation methods affect crop pollinators, we compared the number of ground-nesting bees nesting and foraging in drip-and furrow-irrigated hybrid sunflower fields in the Sacramento Valley. We found that irrigation method did not impact wild bee nesting rates or foraging bee abundance or bee species richness. These findings suggest that changing from furrow irrigation to drip irrigation to conserve water likely will not alter hybrid sunflower crop pollination.

$\mathrm{I}$ rrigation practices and water use efficiency are increasingly scrutinized by growers. Irrigated agriculture accounts for $80 \%$ of human-related water use in California (DWR 2013). In periods of drought, growers adopt water-saving irrigation practices at higher rates (Schuck et al. 2005).

Drip irrigation, introduced to California in
1969, delivers water directly to the plant root zone, thus improving water efficiency; it is now used in approximately $40 \%$ of all irrigated fields (Taylor et al. 2014). Increases in irrigation efficiency can improve yield (Tilman et al. 2002; Wallace 2000), which is another reason growers may consider switching to drip irrigation. However, changes in irrigation practices may negatively impact other factors that determine crop success, such as pollination.

Wild bees are the most effective and abundant crop pollinators (Garibaldi et al. 2013). The majority of wild bees excavate nests beneath the soil (known as ground nesters). Irrigation has the potential to saturate nests, possibly drowning bee larvae and adults. It could also indirectly impact crop pollinators by affecting their foraging choices. Bee foraging decisions are often related to floral reward, namely nectar quantity and quality (Roubik and Buchmann 1984; Stone 1994). Nectar production is related to water availability; increased water leads to higher nectar volume expressed (e.g., Petanidou et al. 1999). Thus, an irrigation method that delivers more water, such as furrow, could make fields more attractive to wild bee pollinators, thereby increasing potential yields.

We compared the number of bees nesting and foraging in conventionally managed hybrid sunflower (Helianthus annuus) fields that were either furrow or drip

Online: https://doi.org/10.3733/ca.2016a0017

Published online September 13, 2016

Findings from a study of Sacramento Valley hybrid sunflower fields suggest that drip irrigation does not have a negative effect on native bee crop pollinators. 
nesting and foraging patterns observed. All fields were located in Yolo County, California.

\section{Bee sampling}

We used 1.96-square-foot emergence traps (BugDorm, MegaView Science, Taiwan) to sample nesting bees (Sardiñas and Kremen 2014; Sardiñas et al. 2016). The traps have open bottoms to allow nesting bees to leave their nest. However, when they emerge, they are funneled to the top of the trap and into a kill jar. We placed the traps at dusk, after bees had returned to their nests, and weighted down the edges with soil to prevent bees from entering or exiting the trap. There were 20 traps in each field along two parallel 328-foot transects that ran into each field (fig. 1). Traps were 32.8 feet apart. Approximately 20 hours later, we removed all bees from apical kill jars (which were filled with soapy water).

The day following emergence trap sampling, we netted foraging bees visiting sunflowers for 30 minutes along each of the two transects. We set emergence traps only if weather conditions the following day were predicted to be ideal for netting: temperature $>64^{\circ} \mathrm{F}$, wind speed $<5.5 \mathrm{mph}$ and low cloud cover (clear skies).

All bees were pinned, then identified by Dr. Robbin Thorp, professor emeritus, UC Davis Department

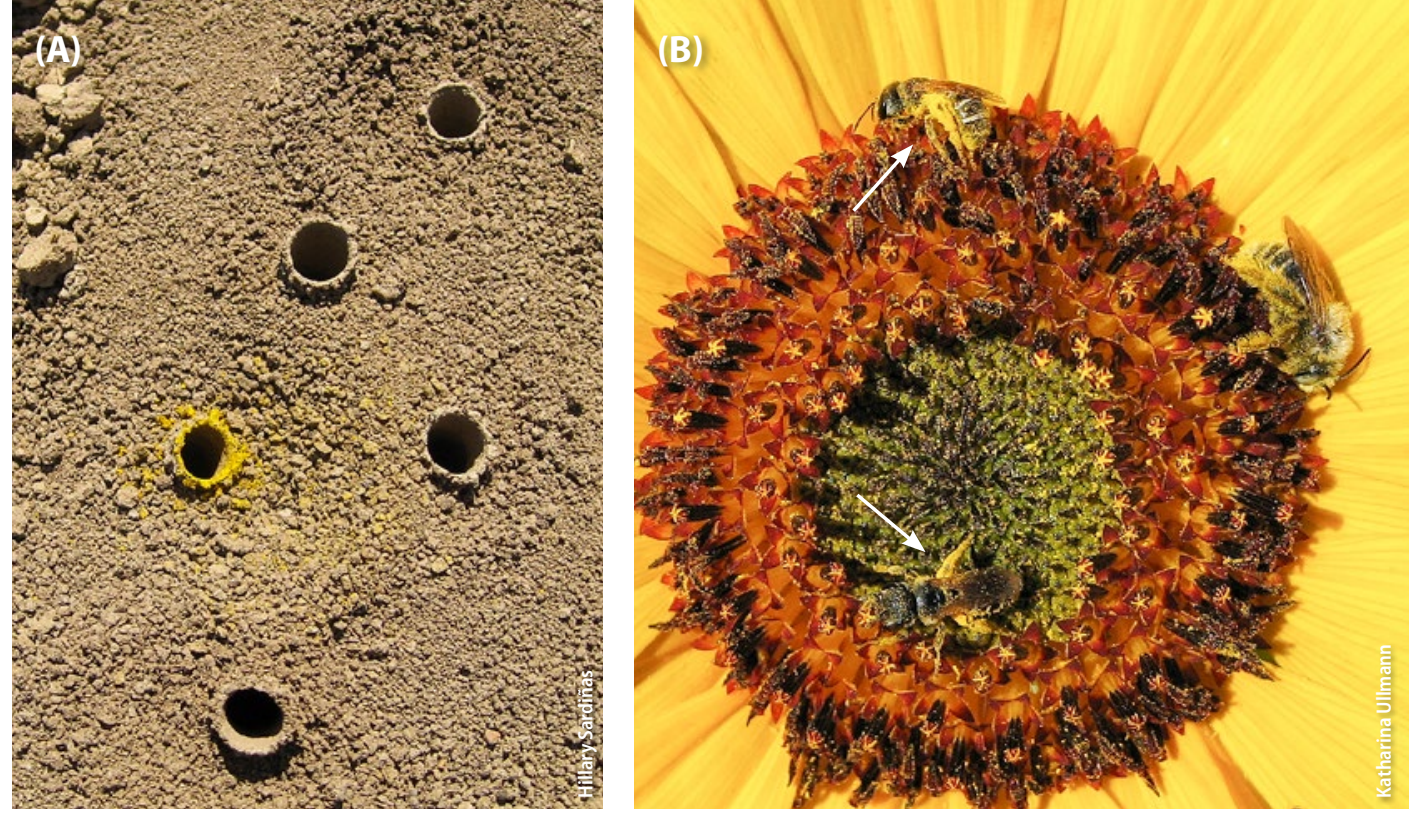

Nest entrances of the ground-nesting sunflower specialist bee, Diadasia enavata (A). Sunflower is visited by both specialist and generalist pollinators, including the generalist Halictus ligatus (B, arrows) and the specialist Diadasia enavata (B).

of Entomology. They are currently housed in UC Berkeley's Essig Museum of Invertebrate Zoology.

\section{Vegetation}

To determine whether vegetative factors influenced bee abundance or species richness, we estimated percentage sunflower bloom, stem density (count of all sunflower stems), weed density (count of all individual weeds) and weed bloom. Sunflower bloom and stem density were correlated, as were weed density and weed bloom, which allowed us to use only one metric for each category in our analyses.

\section{Statistical analyses}

We examined the effect of irrigation method on the abundance of nesting bees captured in emergence traps and foraging bees netted at blooms using a generalized linear model with a Poisson distribution in the R package lme4 (Bates et al. 2015). Independent variables were irrigation type, stem density and weed density. Site was a random effect. We repeated this analysis for species richness, which was calculated using the $R$ package vegan (Oksanen et al. 2013). We included only female bees in our analyses of nesting rates, as male bees do not excavate nests (Kim et al. 2006).
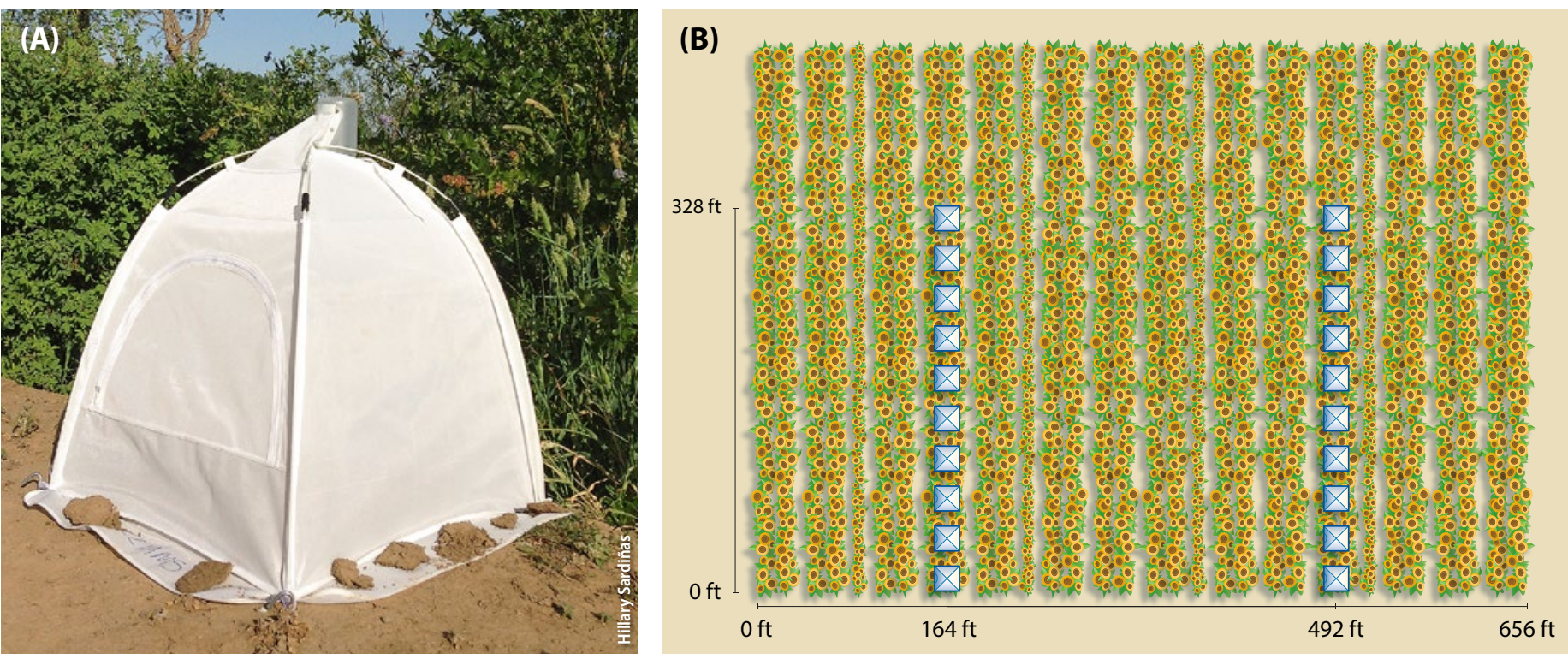

Fig. 1. Emergence traps (A) were used to collect bees nesting in sunflower fields and were placed along two parallel transects (B) running 328 feet into the fields. Transects were located 164 feet from field edges and 328 feet apart. Ten traps (white boxes, B), 32.8 feet apart, were placed along each transect. 


\section{Bee nesting and foraging counts}

We collected 42 bees from six species nesting within fields and 735 bees from 14 species foraging on sunflower blooms (table 1). All of the species we collected nesting were also found foraging. The two most abundant species nesting in sunflower fields were the sunflower specialist Melissodes agilis and the generalist sweat bee Lasioglossum incompletum. These bees were among the most abundant bee species found foraging. One other species of sweat bee (Halictus ligatus) and three other sunflower specialist bees (Diadasia enavata, $M$. robustior and Svastra obliqua expurgata) foraged in high

TABLE 1. Species collected nesting in sunflower fields and foraging on sunflowers

\begin{tabular}{|c|c|c|c|}
\hline Species & Specialization & Nesting & Foraging \\
\hline Bombus vosnesenskii & Generalist & 0 & 1 \\
\hline Diadasia enavata & Specialist & 0 & 53 \\
\hline Halictus ligatus & Generalist & 1 & 51 \\
\hline Halictus tripartitus & Generalist & 1 & 20 \\
\hline Lasioglossum (Dialictus) spp. & Generalist & 6 & 1 \\
\hline Lasioglossum incompletum & Generalist & 16 & 43 \\
\hline Megachile parallela & Specialist & 0 & 1 \\
\hline Melissodes agilis & Specialist & 17 & 393 \\
\hline Melissodes lupina & Specialist & 0 & 8 \\
\hline Melissodes robustior & Specialist & 0 & 63 \\
\hline Peoponapis prunoisa & Specialist* & 0 & 1 \\
\hline Svastra obliqua expurgata & Specialist & 0 & 88 \\
\hline Triepeolis concavus & Parasite & 0 & 3 \\
\hline Triepeolis subnitens & Parasite & 1 & 9 \\
\hline Total no. of bees & & 42 & 735 \\
\hline Total no. of species & & 6 & 14 \\
\hline
\end{tabular}

* Specialist of squash, not sunflower.
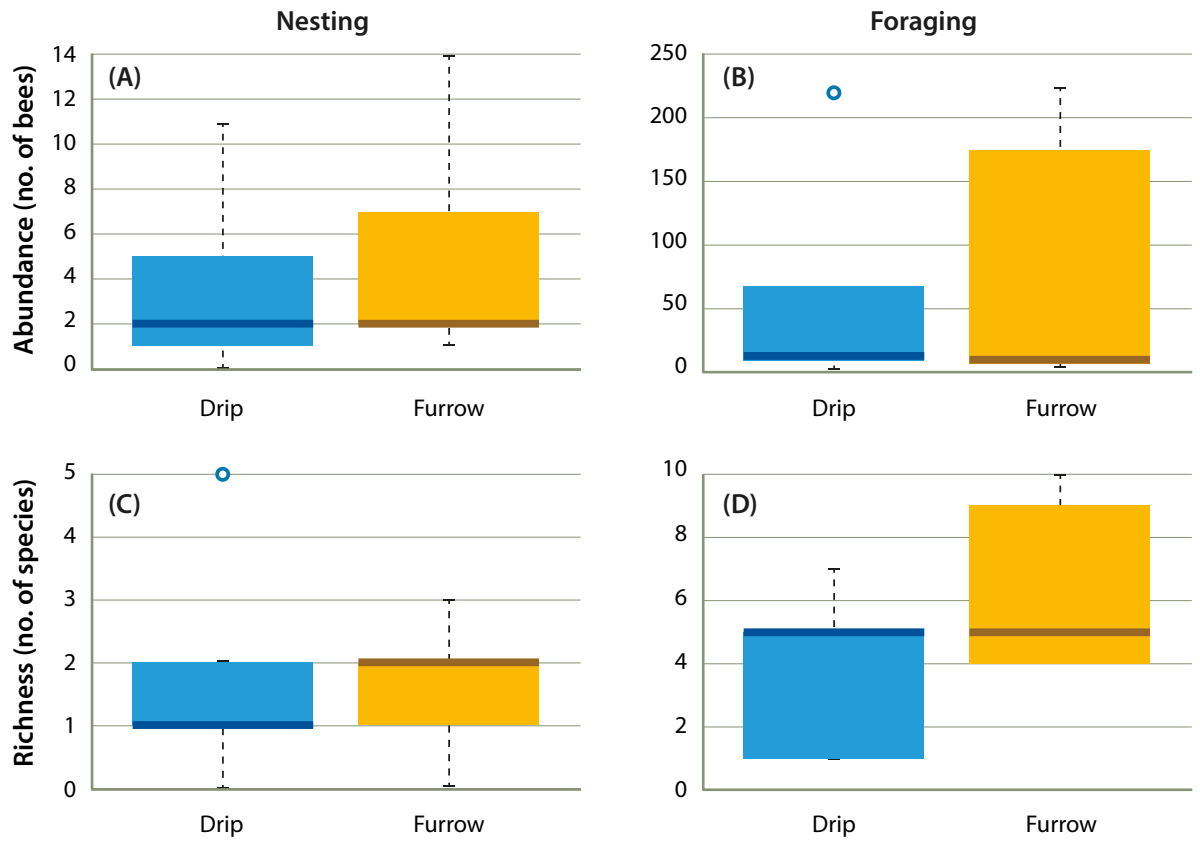

Fig. 2. Irrigation method did not affect the abundance or species richness of nesting bees $(A, C)$ or foraging bees (B, D) in sunflower fields. Boxes are upper and lower quartiles, dark bar is the mean, whiskers show the maximum and minimum values, and points are outliers.

numbers, yet were not detected nesting within fields.

\section{Bee response to irrigation method}

We did not find a difference in the abundance of bees nesting in drip- versus furrow-irrigated fields (fig. 2A; $z=0.29$, $P=0.77)$. Similarly, the species richness of nesting bees did not vary with irrigation type (fig. $2 C ; z=-0.40, P=0.68$ ). Sunflower stem density $(z=0.71, P=0.48)$ and weed density $(z=-0.15, P=0.85)$ did not impact nesting rates (data not shown), which is not surprising given that we attempted to control for variability in bloom by sampling at peak bloom in all fields (> $90 \%$ of stems in bloom).

As with nesting rates, the abundance (fig. 2B; $z=0.12, P=0.89$ ) and species richness (fig. $2 \mathrm{D} ; z=1.60, P=0.11$ ) of native bees actively foraging on sunflower was unaffected by irrigation type. Sites that were sampled at the same time appeared to contain similar numbers of foraging bees (fig. 3) except for sites D3 and F3, where the drip-irrigated site contained almost twice as many foraging bees. However, we were unable to assess the effect of sampling date in our analyses as each site was sampled only once.

\section{Study sample size}

This study was conducted during a single year; therefore, the results reflect nesting and foraging during this one sampling season. Our sample size may not have been large enough to detect small differences in nesting rates. While the strength of the nesting results indicates that sunflower bee nesting is likely not linked to irrigation method, additional evidence from future studies could help confirm this conclusion. We collected numbers and species of bees in our netted sample that were similar to those in other studies in sunflower in our study region (Greenleaf and Kremen 2006a; Sardiñas and Kremen 2015); this similarity suggests our findings on the relationship of foraging bees to irrigation type may be robust to the effects of small study size.

\section{Soil moisture conditions}

Soil moisture has been shown to positively affect nesting (Julier and Roulston 
(Ayars et al. 2015). Over 85\% of processing tomato fields in California have been converted to drip irrigation systems, which has increased yields without compromising crop quality (Taylor et al. 2014). Sunflower is often rotated into fields that contained tomato the year prior because
(Jackson et al. 2011). The current drought is driving up the cost of water and limiting water access, leading growers to increase well drilling to obtain groundwater (Daniel Munk, UC Cooperative Extension, personal communication). Wells were expected to account for $53 \%$ of all irriga-

\section{Drip irrigation is a viable method to combat the drought without compromising crop pollination from wild bees.}

the two crops have similar row spacing. Growers leave the drip tape down $(\mathrm{H}$. Sardiñas, personal observation), maximizing their investment through reuse of the drip tape.

Water efficiency is especially important in California's Central Valley, where climate change is expected to increase temperatures $2^{\circ} \mathrm{F}$ to $3.6^{\circ} \mathrm{F}$ by 2050 and the frequency, intensity and duration of summer heat waves are expected to increase tion water in 2015; however, increased rates of pumping caused by the prolonged drought has caused the water level to drop below the depth of many wells (Howitt et al. 2014); this excess pumping is also leading to land subsidence.

Although this study was conducted in hybrid sunflower fields, the irrigation methods applied are typical of those used in row crops throughout the Central Valley. The generalist sweat bees that nest and forage on sunflower are among the most common crop pollinators in the region, and pollinate a variety of crops from watermelon to tomato (Greenleaf and Kremen 2006b; Morandin and Kremen 2013). We would therefore expect our findings to apply to a number of different annual crop types.

The combined efficiency benefits and lack of negative effects on native bee crop pollinators indicate that drip irrigation is a viable method to combat the drought without compromising crop pollination from bees nesting within crop fields. CA

H. Sardiñas is Pacific Coast Pollinator Specialist at the Xerces Society for Invertebrate Conservation, Berkeley; C. Yee participated in this research as part of her undergraduate thesis at UC Berkeley; and C. Kremen is Professor in the Department of Environmental Science, Policy and Management at UC Berkeley.

\section{References}

Ayars JE, Fulton A, Taylor B. 2015. Subsurface drip irrigation in California - Here to stay? Agr Water Manage 157:39-47. doi:10/1016/j.agwat.2015.01.001 Bates D, Marchler M, Bolker B, Walker S. 2015. Fitting linear mixed-effects models using Ime4. J Stat Softw 67(1):1-48. doi:10.18637/jss.v067.i01.

Cane JH. 1981. Dufour's gland secretion in the cell linings of bees (Hymenoptera: Apoidea). J Chem Ecol 7(2):403-10.

Cane JH. 1997. Violent weather and bees: Populations of the Barrier Island endemic Hesperapis oraria (Hymenoptera: Melittidae) survive a category 3 hurricane. J Kansas Entomol Soc 70(1):73-5. www.jstor.org/stable/25085754. [DWR] Department of Water Resources. 2013. California Water Plan, Vol. 5. www.waterplan.water.ca.gov/technical/cwpu2013/index.cfm\#general (accessed Oct. 26, 2015).

Fellendorf M, Mohra C, Paxton RJ. 2004. Devastating effects of river flooding to the ground-nesting bee, Andrena vaga (Hymenoptera: Andrenidae), and its associated fauna. J Insect Conserv 8(4):311-22. doi:10.1007/ s10841-004-0514-5.

Garibaldi LA, Steffan-Dewenter I, Winfree R, et al. 2013. Wild pollinators enhance fruit set of crops regardless of honey bee abundance. Science 339(6127):1608-11. Greenleaf SS, Kremen C. 2006a. Wild bees enhance honey bees pollination of hybrid sunflower. Proc Nat Acad Sci 103:13890-5.

Greenleaf SS, Kremen C. 2006b. Wild bee species increase tomato production and respond differently to surrounding land use in Northern California. Biol Conserv 133(1):81-7.

Howitt RE, Medellin-Azuara J, MacEwan D, et al. 2014 Economic Analysis of the 2014 Drought for California Agriculture. Center for Watershed Sciences, UC Davis, California. http://watershed.ucdavis.edu (accessed Nov. 4, 2015).
Hurd PD, Wallace-LaBerge E, Linsley GE. 1980. Principal sunflower bees of North America with emphasis on the Southwestern United States (Hymenoptera: Apoidea). Sm C Zoology 310:1-158. www.sil.si.edu/smithsoniancontributions/zoology/pdf hi/sctz-0310.pdf (accessed Nov. 4, 2015).

Jackson LE, Wheeler SM, Hollander AD, et al. 2011. Case study on potential agricultural response to climate change in a California landscape. Climatic Change 109(1):407-27.

Julier HE, Roulston T. 2009. Wild bee abundance and pollination service in cultivated pumpkins: farm manage ment, nesting behavior and landscape effects. J Econ Entomol 102(2):563-73.

Kim J, Williams NM, Kremen C. 2006. Effects of cultivation and proximity to natural habitat on ground-nesting native bees in California sunflower fields. J Kansas Entomol Soc 79(4):309-20.

Morandin LA, Kremen C. 2013. Hedgerow restoration promotes pollinator populations and exports native bees to adjacent fields. Ecol Appl 23(4):829-39.

Oksanen J, Blanchet FG, Kindt P, et al. 2013. Vegan: Community Ecology Package. http://CRAN.R-project.org/ package= vegan.

Parker FD, Tepedino VJ, Bohart GE. 1981. Notes on the biology of a common sunflower bee, Melissodes (Eumilissodes) agilis Cresson. J NY Entomol Soc 89(1):43-52. www.jstor.org/stable/25009235.

Petanidou T, Goethals V, Smets E. 1999. The effect of nutrient and water availability on nectar secretion and nectary structure on the dominant Labiatae species of phrygana. Syst Geograph Plants 68:233-44.

Roubik DW, Buchmann SL. 1984. Nectar selection by Melipona and Aplis mellidera (Hymenoptera: Apidae) and the ecology of nectar intake by bee colonies in a tropical forest. Oecologia 61(1):1-10.

Rust RW, Cambon G, Vaissiere BE. 2004. Biology of No mioides variegatus (Olivier) (Hymenoptera: Halictidae) Annales de la Societe entomologique de France (N.S.) 40(3-4):269-76. doi:10.1080/00379271.2004.10697425.
Sardiñas HS, Kremen C. 2014. Evaluating nesting microhabitat for ground-nesting bees using emergence traps. Basic Appl Ecol 15(2):161-8. doi:10.1016/j. baae.2014.02.004.

Sardiñas HS, Kremen C. 2015. Pollination services from field-scale agricultural diversification may be contextdependent. Agr Ecosyst Environ 207:17-25.

Sardiñas HS, Tom K, Ponisio LC, et al. 2016. Sunflower (Helianthus annuus) pollination in California's Central Valley is limited by native bee nest site location. Ecol Appl 26:438-47. doi:10.1890/15-0033.

Schuck EC, Fraiser WM, Webb RS, et al. 2005. Adoption of more technically efficient irrigation systems as a drought response. Water Res Devel 21(4):651-62. doi:10.1080/07900620500363321.

Shock CC. 2013. Drip irrigation: An introduction. Oregon State University Extension. EM 8782. https://catalog. extension.oregonstate.edu/sites/catalog/files/project/ pdf/em8782.pdf.

Stone GN. 1994. Activity patterns of females of the solitary bee Anthophora plumipes in relation to temperature, nectar supplies and body size. Ecol Entomol 19(2):177-89.

Taylor R, Parker D, Zilberman D. 2014. Contribution of University of California Cooperative Extension to Drip Irrigation. http://giannini.ucop.edu/media/are-update/files/ articles/N18N2_2.pdf (accessed Oct. 26, 2015).

Tilman D, Cassman KG, Matson PA, et al. 2002. Agricultural sustainability and intensive production practices. Nature 418(6898):671-7. doi:10.1038/nature01014.

Wallace JS. 2000. Increasing agricultural water use efficiency to meet future food production. Agr Ecosyst Environ 82(1):105-19. doi:10.1016/S0167-8809(00)00220-6.

Xie Z, Qiu J, Chen X. 2013. Decline of nest site availability and nest density of underground bees along a distance gradient from human settlements. Entomol Sci 16(2):170-8. 